\title{
Early Detection Of Existence Of Ova In Nail Of Primary School Children Viewed From Personal Hygiene State Elementary School
}

\author{
Yenny Puspitasari \\ Institute of Health and Science Surya Mitra Husada Kediri \\ Kediri, Indonesia \\ Yenny_puspita80@yahoo.co.id
}

\author{
Maulina Nurikasari \\ Institute of Health and Science Surya Mitra Husada Kediri \\ Kediri, Indonesia \\ Molly.gommez@gmail.com
}

\begin{abstract}
The general purpose of this research is to know the correlation among personal hygiene and the ova on the nails of primary school students at State Elementary School Sentul 2 of Blitar. This research is kind of analytic observation by using cross sectional methods. The population of this research is the number of 455 students. The samples taken were 82 respondents by using cluster random sampling. The independent variable was personal hygiene and the dependent variable was the existence of the ova on the nails. The instrument used in this research is questioner by centrifuged method. These tested using logistic regression statistical test. The result of the research show that almost respondent have good personal hygiene, the category is 72 respondent $(88 \%)$ and 27 respondent $(33 \%)$ found ova on their nails. The test results obtained using logistic regression sig $p$ $=0.010$. Because the value of $p<0.05$ then $H_{0}$ is rejected, which means there is correlation between personal hygiene and the existence of the ova on the nails of the primary students at State Elementary School Sentul 2 of Blitar. Based on the research result we can conclude there is correlation between the existence of the ova on the nails and the personal hygiene. Therefore it is occurrence of the worm.
\end{abstract}

Keywords; Personal hygiene, ova, helminthiasis

\section{INTRODUCTION}

Worm infection disease is one disease that is still prevalent in society but received less attention. Deworming is a neglected disease (neglected disease) is an infection that is overlooked and the disease is chronic without causing obvious clinical symptoms and the impact of new looks in the long term. This disease does not cause outbreaks appear suddenly or cause a lot of casualties, but it is a disease that slowly eats away human health, causing permanent disability, decreased intelligence of the child and may eventually also lead to mortality [1]

Based on preliminary studies that have been conducted by investigators on March 16, 2016 at State Elementary School Sentul 2 of Blitar by taking a sample as many as 10 students of a number of students were 455 students showed that 7 of nail samples found positive student containing worm eggs. Where including 5 samples contained eggs of Ascaris lumbricoides and 2 samples contained eggs of the worm Trichuris trichiura.

Long nails and untreated will become a place of attachment of debris that contains a variety of materials and microorganisms such as bacteria and worm eggs. Transmission of worms including through the fingernails were dirty. Dirty fingernails tucked worm eggs which may be swallowed when eating; this is compounded if not used to wash hands with soap before eat [2]. Worm infections generally enter through the mouth, or directly through cuts in the skin (hookworm and yarn), worms that enter can be eggs, cysts or larvae, which is above the ground. When the worm eggs into the belly and he will soon hatch in the small intestine and immediately undermined the patient's body and absorb the juices of the food or the essential substances needed by the body. This is what can lead to anemia, nutritional deficiencies in children as well as slow growth in child [3].

Given the impact caused by this worm infection it is important to do a comprehensive effort to establish a baseline in the strategic policy of prevention and the establishment of appropriate worm control programs. So far in Blitar yet there is an early detection program conducted by the local Health Department in knowing their worm disease cases in children. It has been done regarding the case of worm infestation is by observing their physical symptoms then newly implemented feces examination for the presence of worms or worm eggs to children who allegedly have been infected worm infection. The purpose of this study was to determine the effect of personal hygiene to the presence of worm eggs in the nail primary school age children in State Elementary School Sentul 2 of Blitar.

\section{METHODS}

The design study is observational, cross sectional approach, in this study population of 455 students, using random cluster sampling technique to obtain the respondents a number of 82 respondents, where personal hygiene is the independent variable and the dependent variable was the presence of worm eggs. Data was collected by using a questionnaire with the centrifuge method. Then it was tested using logistic regression statistical test. 


\section{RESULTS}

TABLE I. CHARACTERISTICS OF RESPONDENTS

\begin{tabular}{cccc}
\hline No & Characteristics & $\Sigma \mathbf{N}$ & $\Sigma \%$ \\
\hline 1 & Age (years) & 42 & 51 \\
& $\mathbf{6 - 8}$ & 26 & 32 \\
$9-11$ & 14 & 17 \\
& $>11$ & & \\
\hline 2 & Gender & & 44 \\
& Male & 36 & 56 \\
\hline 3 & Female & 46 & 0 \\
& Personal hygiene & 12 \\
& Less & 0 & 88 \\
\hline 4 & Enough & 10 & \\
& Good & 72 & 33 \\
& Positive & The existence of ova & $\mathbf{6 7}$ \\
\hline & Negative & 27 & 100 \\
\hline
\end{tabular}

According to the table 1 above is known that most of the respondents were in the age range of 6-8 years in the amount of $51 \%$ (42 people), female is equal to $56 \%$ (46 people), have high levels of personal hygiene in good category were 72 respondents $(88 \%)$ and the presence of worm eggs in the nails of students at State Elementary School Sentul 2 of Blitar, obtained 27 respondents (33\%) positive.

Based on the test is obtained $\mathrm{p}$ equal to 0.010 . Because the $\mathrm{p}$-value $(0.010)<\alpha(0.05)$, then $\mathrm{H} 0$ rejected and $\mathrm{H} 1$ accepted in other words the influence of personal hygiene There are against the presence of worm eggs in the nail primary school age children in State Elementary School Sentul 2 of Blitar Nagelkerke R-square value is 0.108 indicates that $10.8 \%$ of the nail where the worm eggs primary school age children in State Elementary School Sentul 2 of Blitar influenced by personal hygiene.

\section{DISCUSSION}

Personal Hygiene Elementary School students in in State Elementary School Sentul 2 of Blitar Based on Table 1 indicates that the characteristics of respondents by personal hygiene students at in State Elementary School Sentul 2 of Blitar, showed most respondents have good personal hygiene category is $72(88 \%)$ of respondents from a total of 82 respondents.

Personal hygiene is personal hygiene that is a measure for maintaining the cleanliness and health of a person's physical and psychological well-being. Personal Hygiene Personal hygiene is an attempt or a person in maintaining cleanliness and health him to obtain physical wellbeing and psychologis [4].

Results of a study of personal hygiene students at State Elementary School Sentul 2 of Blitar can be categorized in three categories: good, sufficient and less. There are 72 respondents $(88 \%)$ having good personal hygiene and $10(12 \%)$ of respondents who have enough personal hygiene. Thus from such exposure relating to aspects of personal hygiene, personal hygiene show that students at State Elementary School Sentul 2 of Blitar is good.

The existence of worm eggs On Nails Childhood Primary School in State Elementary School Sentul 2 of Blitar.

In Table 1 it can be concluded that as many as 55 respondents $(67 \%)$ negative is not found in samples of worm eggs nails, and as many as 27 respondents (33\%) found positive samples of worm eggs on her nails.

Long nails and untreated will become a place of attachment of worm eggs. Transmission of worms including through the fingernails were dirty.

The existence of worm eggs in the child's fingernails can be affected by various factors, among others factors, soil moisture that are a breeding ground for worms, the climatic conditions of a region, neighborhood seedy behavior of children which is usually the incidence of worm commonly found in communities with hygiene and sanitation less [5].

From the research there was a tendency of respondents are male more positive discovered worm eggs on nails, this may be due to differences craze among girls and boys. Where the boys prefer to play on the ground for example is a game of marbles, soccer and others, while girls usually prefer to play on the patio or in the house.

Based on the results of the study, it also showed that children who have a good personal hygiene category were less likely to be found on the fingernails of worm eggs. It is proven that by maintaining personal hygiene can prevent the spread of self worm eggs into the body. Such as keeping nails with a routine way to cut the nails when they are long, keeping the nail hygiene by cleaning the nails if there is dirt, wash hands with soap after holding the animals, defecation or small, play ground and before eating, hygiene leg with footwear using any activity outside the home and always keep the body in a bath at least 2 days using soap. With these measures is expected to prevent the transmission of eggs or worms that cause worm infection.

Early Detection of presence of worm eggs On Nails Childhood Elementary School Evaluated Based on Personal Hygiene in State Elementary School Sentul 2 of Blitar Personal hygiene in this study was measured using a questionnaire to five indicators: body hygiene, hand washing, hygiene nail, and foot hygiene habits in contact with the ground. On the results of the data analysis using logistic regression statistical test known the value $\mathrm{p}=0,010$ which is smaller than the value of $\alpha(0.05)$. This shows that the hypothesis is accepted, which means personal hygiene There is an effect of the existence of worm eggs in the nail primary school age children. While the value of $\mathrm{R}$ square Nagelkerke indicate that that $10.8 \%$ of the nail where the worm eggs primary school age children in primary schools in State Elementary School Sentul 2 of Blitar influenced by personal hygiene. Personal hygiene purpose is to improve the health of a person, a person maintain personal hygiene, improving personal hygiene is lacking, preventing illness, increase a person's confidence and create the beauty of a person's body. Therefore, 
maintaining good personal hygiene is essential for maintaining the health of 18 persons.

Based on research results also indicate that by maintaining good personal hygiene will be able to reduce their ova on the nails, on the contrary that the category of personal hygiene or lack enough can lead to the transmission of helminthes eggs in children. Even children with good personal hygiene category can also be positive discovered worm eggs on her nails.

\section{CONCLUSION}

Further improve personal hygiene, especially related to hygiene nails. Routine cut nails and clean the nails by soaking your nails in warm water and salt mixture that dirt on the hoof can be lost. Should avoid the habit of playing the land, because the land is home to a worm eggs. De-worming regularly eat at regular intervals to prevent the development of worms that cause worm infection.

Need to make a promotional effort in preventing prevalence of worm infections for considering this has never been a program for the infectious disease, by means of microscopic examination of nail hygiene.
Conduct health promotion efforts related to worm infestation and personal hygiene as well as providing regular worm medicine to students of primary school age to prevent early onset of worm infection.

\section{REFERENCES}

[1] Junaidi, "Hubungan Personal Hygiene Terhadap Kejadian Kecacingan Pada Murid SD di Wilayah Kerja Puskesmas Tapalang Kabupaten Mamaju. Jurnal Ilmiah Kesehatan Diagnosis,” 2014.

[2] N. . Rahmadhini and M. Hanna, "Pemeriksaan Kuku Sebagai Alternatif Dalam Mendiagnosis Kecacingan.,” 2015.

[3] A. Zulkoni, Parasitologi. Yogyakarta: Nuha Medika, 2011.

[4] [Mubarak, W. Iqbal, and N. Cahyatin, Buku Ajar Kebutuhan Dasar Manusia Teori \& Aplikasi Dalam Praktik. Jakarta: EGC, 2008.

[5] W. R. Mulyanti and H. Astuty, "Upaya Pemberantasan Kecacingan di Sekolah Dasar," Makara, 2012. 